\title{
Cryptomyces maximus rediscovered in Finland after 99 years
}

\author{
TEPPO RÄMÄ
}

\begin{abstract}
RÄMÄ, T. 2016: Cryptomyces maximus rediscovered in Finland after 99 years. Karstenia 56: 55-60. HELSINKI. ISSN 0453-3402.

Cryptomyces maximus is a conspicuous ascomycete, which is easy to identify due to its characteristic ecology and morphological appearance. The fungus was found in three locations in the northwesternmost part of the country, 99 years after the first find in Southern Finland in 1913. Four recent records made in Northern Norway are also published. The host range of the fungus is expanded with three willow species.
\end{abstract}

Key words: Ascomycota, fungal parasitism, Rhytismataceae, Twig Girdling, Willow Blister

Teppo Rämä, Marbio, Norwegian College of Fishery Science, University of Tromsø The Arctic University of Norway, Postbox 6050 Langnes, NO-9037 Tromsø, Norway; e-mail: teppo.rama@uit.no

\section{Introduction}

The Finnish mycologist Toivo Johannes Hintikka collected Cryptomyces maximus (Fr.: Fr.) Rehm (Rhytismataceae, Leotiomycetes) as new to Finland in May 1913. The fungus was found growing on the willow species Salix myrsinifolia ssp. myrsinifolia Salisb. in Joroinen, which is located at low-altitude in Pohjois-Savo biogeographical province in the southern boreal vegetation zone (Påhlsson \& Danielsson 1977). This fungus is restricted to willow species as hosts, is relatively big in size and easy to identify, hence it is remarkable why it has remained undiscovered in Finland all the time since Hintikka's collection.

Older records have also been made in other Nordic countries, in the Mediterranean and in central parts of Europe - and in North America - spanning in time from the oldest record in England in 1801 (Sowerby 1803; as Sphaeria aurea Sowerby) to those from Northern Norway in 1926 (Jørstad 1928). The fungus was infrequently recorded in the mid-1900s, whereas in the $21^{\text {st }}$ century it has been reported from several locali- ties in Norway, Wales, UK and once in Sweden (Granmo et al. 2012). The fungus is considered a world-class rarity and has consequently been included in the top 100 most threatened species in the world (Baillie \& Butcher 2012), though not included in red-lists yet. In Norway and Sweden the fungus is classified as not evaluated (NE) and least concern (LC), respectively (Artdatabanken 2015, Artsdatabanken 2015). Cryptomyces maximus has been found 38 times in the Nordic countries including 12 recent collections, made in 2008-2011, from Northern Norway (Granmo et al. 2012).

Cryptomyces maximus grows on living willow species in habitats with humid microclimate, such as brook side thickets, mire edges and woody mires. In Northern Fennoscandia it is most frequently found in natural habitats, although it is not restricted to these, as evidenced by the ditch-side habitat reported by Granmo et al. (2012). Cryptomyces maximus seems to prefer northern and alpine areas, but has also been found in lowlands in Northwestern Germany and Western UK (Granmo et al. 2012). The fungus 
is a parasite occurring on many willow species, but seems to favor Salix phylicifolia L., S. myrsinifolia and $S$. × smithiana Willd. (S. lanceolata) as hosts in the Nordic countries (Granmo et al. 2012). The branches carrying fruit bodies of this fungus can often be spotted from a distance, as they usually have less, and more apically located leaves than uninfected branches. This may be due to the parasite partially circumscribing the branch, penetrating host's epidermal and cortical cells with nutrient exploiting hyphae and thus preventing normal leaf formation along the branch.

Fruit bodies of Cryptomyces maximus resemble the stromata of some diatrypaceous ascomycetes and appear as convex, irregular dark or black swellings under the periderm of living willow branches and stems (Fig. 1). The stromata are most colorful in the beginning of the growing season (spring - early summer), when the black parts are contrasted by a surrounding yellow - orange zone (see Fig. 1 in Granmo 2011). On maturing, the host's periderm and upper parts of stroma peel off starting from the middle, and gives the fungus an exploded appearance (see Fig. $1 \mathrm{~d}$ in Granmo et al. 2012). The ascospores have a slimy perispore with hair-like apical extensions that indicates animal-associated dispersal (Fig. 1; Webster 1980, Magyar et al. 2016). The fragrant, honey-like smell may also serve for better dispersal with animal vectors. Details about the ecology, appearance and microscopic characteristics of this fungus can be found in Minter \& Cannon (2001) and Granmo et al. (2012).

\section{Results and discussion}

During fieldwork in Northern Fennoscandia in 2012-2016, seven new collections of Cryptomyces maximus were made. Two of the collections were found in the same Norwegian locality at different years (2012 and 2016, Grønnlibruna $\mathrm{N})$, and hence the number of new locations is six. The fungus was rediscovered in Finland after 99 years, when it was found at Kilpisjärvi in 2012 (Fig. 2). The search efforts made to detect Cryptomyces in Finland (by the author) have been modest, comprising of less than 15 person-hours of searching in suitable habitats in southern and northern parts of the country. Granmo et al. (2012) expected that more localities would ap- pear, when the fungus becomes better known and is systematically searched for. Finnish mycologists were encouraged to look for $C$. maximus (Rämä 2013), but, except for the author's collections, no new records have been made since Granmo et al. (2012). Documented Salix hosts (see below) are common especially in Northern Fennoscandia and their stands often cover large areas. The seeming rarity of $C$. maximus remains a mystery and poses many questions. Is the possible animal-assessed spore dispersal inefficient? Or is the fungus just a weak parasite that most willow individuals are able to defeat before the formation of fruit bodies?

The temporal, discontinuous distribution of C. maximus remains unexplained. There are several records from Northern and Central Europe from 1875 until 1928, but thereafter an almost 50-year gap with no records at all. In 1971, the species was found as new to Iceland, and in the $21^{\text {st }}$ century the species has been found in several places in Northern Fennoscandia and elsewhere (Granmo et al. 2012). Had mycologists in the mid-1900s just forgotten this ascomycete, or did they not know where to search for it? Or perhaps was the European population of $C$. maximus declining due to changes in the population size of potential dispersal hosts? Nevertheless, the spatio-temporal distribution patterns and dispersal strategies of this fungus remain poorly understood, and warrant further studies of this mysterious ascomycete.

The recent fieldwork efforts resulted in the detection of three new host species of Cryptomyces maximus, as it was spotted on Salix lapponum L. and S. cf. glauca ssp. stipulifera (Flod. ex Häyrén) Hiitonen in Kilpisjärvi (Finland) and $S$. hastata L. in Skibotn (Norway). The detection of new hosts was unsurprising, as the species previously has been observed on at least 15 different host species, including big trees $(S$. alba L., $S$. pentandra L., S. fragilis L., S. caprea $x$ viminalis, $S$. caprea x myrsinifolia), erect shrubs ( $S$. phylicifolia, S. myrsinifolia) and low procumbent ascending shrubs (S. arbuscula L.) (cf. Granmo et al. 2012). Although the fungus clearly prefers some Salix species over others, future search on this willow-specialist should consider all Salix species that are growing in habitats with humid microclimate. 

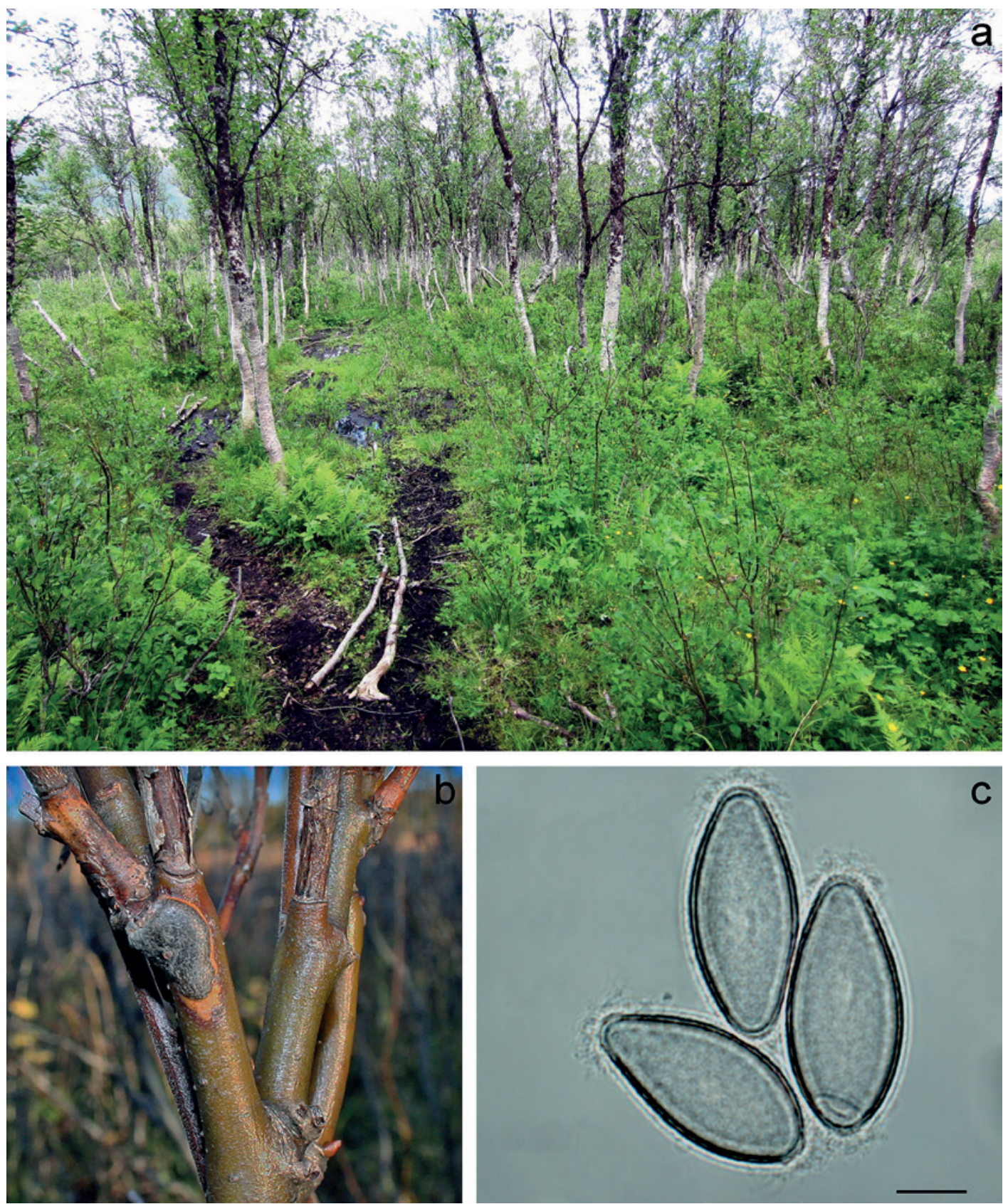

Fig. 1. Cryptomyces maximus. $\mathrm{a}=$ habitat of the species in Tromsø, Grønnlibruna N. b = mature stroma (Tromsø, Grønnlibruna N, 9.X.2016 A., U., H.\& T. Rämä 2016-05 (TROM)). c = spores (Granmo AG4/08 (TROM)). Scale = 10 $\mu$ m. - Photos: a-b T. Rämä; c A. Granmo. 


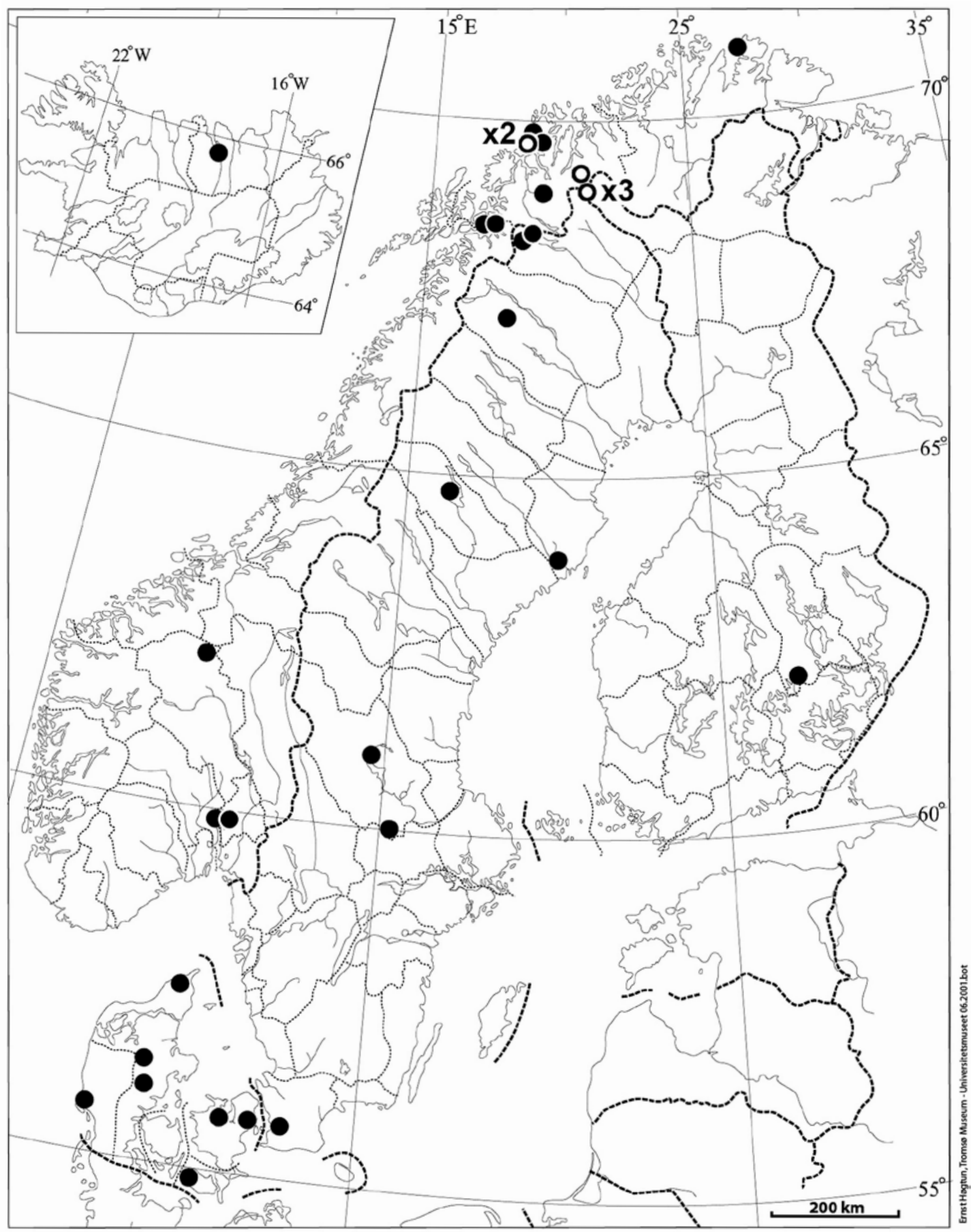

Fig. 2. Cryptomyces maximus. Nordic distribution until October $2016 \bullet=$ localities found before May 2012 (Granmo et al. 2012, one dot may represent several finds), $\mathrm{o}=$ new localities. Map modified after Granmo et al. (2012). 
Finnish material of Cryptomyces maximus: Pohjois-Savo. Joroinen, Lemmetti, Salix myrsinifolia ssp. myrsinifolia, 23.V.1913 Hintikka (H; duplicates in TUR and TUR-A), same place and host species, V.1913 Hintikka (TROM ex H). Enontekiön Lappi. Enontekiö, Kilpisjärvi, by parking lot of Kilpisjärvi Biological Station, 69²'36”N 2048'18'E, moist subalpine rich grove with mountain birch and $\mathrm{Sa}$ lix shrubs, on four S. hastata / phylicifolia individuals, 18.VIII.2012, A. \& T. Rämä 2012-03 (TROM), SW slope of Saana, by hiking track, $69^{\circ} 2^{\prime} 32^{\prime \prime} \mathrm{N} 20^{\circ} 49^{\prime} 4^{\prime \prime} \mathrm{E}$, rich fen with Tomentypnum nitens and Sphagnum warnstorfii, on two shoots of one $S$. cf. glauca ssp. stipulifera individual. 14.IX.2013, U. \& T. Rämä 2013-03 (TROM), Muotkatakkavaara, near parking lot, $68^{\circ} 55^{\prime} 29^{\prime \prime} \mathrm{N} 20^{\circ} 56^{\prime} 10^{\prime \prime} \mathrm{E}$, on shore of small pond, on S. lapponum, 9.VIII.2013, T. Rämä 2013-02 (TROM).

\section{New Norwegian finds of Cryptomyces maximus (for older records, see Granmo et al. 2012):}

Troms. Tromsø, Kvaløya, Grønnlibruna N, on east side of hiking path, $10 \mathrm{~m}$ from the path before the steep slope in S, 69³6'30'N 18 42'20"E, eutrophic-mesotrophic woody mire with Betula pubescens, Salix caprea, Salix spp., Equisetum hyemale and Trollius europaeus, on S. myrsinifolia ssp. myrsinifolia, 8.IX.2012, A., H., U. \& T. Rämä 2012-02 (TROM), same place, on $\mathrm{Sa}$ lix sp., 9.X.2016, A., U., H. \& T. Rämä 201605 (TROM), Tisnes, 693' 54'N 1849'25'E, between wet horse pasture with ponds and the road, on Salix phylicifolia, 8.VII.2013, Nikkinen \& T. Rämä 2013-01 (TROM), Storfjord, Skibotn, Skibotndalen, Helligskogen, 69 $14^{\prime} 4^{\prime \prime} \mathrm{N}$ 20.38'36"E, by river, on Salix hastata, 11.VI.2016, A., U. \& T. Rämä 1-16 (TROM).

Acknowledgements: Many thanks to Aarni, Heini and Unni Rämä, and Lauri Nikkinen for assisting in the field, Ernst Høgtun for preparing Fig. 2., Alfred Granmo for providing permission to use his migrograph for Fig. 1, and A. Granmo and Geir Mathiassen for manuscript comments and sharing their Cryptomyces maximus knowledge with me.

\section{References}

Artdatabanken 2015: Artfakta. ArtDatabanken SLU. Retrieved October 26, 2016 from http://artfakta.artdatabanken.se/\#

Artsdatabanken 2015: Norsk rødliste for arter. Artsdatabanken. Retrieved October 26, 2016 from http://data. artsdatabanken.no/Rodliste

Baillie, J. \& Butcher, E. 2012: Priceless or Worthless? The world's most threatened species. Zoological Society of London: United Kingdom. Retrieved October 26, 2016 from https://static.zsl.org/files/priceless-orworthless-final-wq-2040-2050.pdf

Granmo, A. 2011: Den gåtefulle Cryptomyces maximus. Blyttia 69: 145-149.

Granmo, A., Rämä, T. \& Mathiassen, G. 2012: The secrets of Cryptomyces maximus (Rhytismataceae). Ecology and distribution in the Nordic countries (Norden), and a morphological and ontogenetic update. Karstenia 52: 59-72.

Jørstad, I. 1928: Nord-Norges skogsykdommer. Tidsskrift for skogbruk 36: 365-456.

Magyar, D., Vass, M. \& Li, D.-W. 2016: Dispersal Strategies of Microfungi. In: Li, D.-W. (eds.). Biology of Microfungi, 315-371. Springer International Publishing, Cham.

Minter, D. \& Cannon, P. 2001: Cryptomyces maximus. IMI Descriptions of Fungi and Bacteria 148: Sheet No. 1473.

Påhlsson, L. \& Danielsson, M. (eds.). 1977: Naturgeografisk regionindelning av Norden. NU-serien (trykt utg.) B 1977: 34. Nordiska Ministerrådet: Stockholm.

Rämä, T. 2013: Cryptomyces maximus 100 vuotta Suomessa. Finnish Mycological Society. Retrieved October 26, 2016 from http://www.funga.fi/blog/ cryptomyces-maximus-100-vuotta-suomessa/

Sowerby, J. 1803: Coloured figures of English fungi or mushrooms 3. Printed by J. Davis: London. Retrieved October 28, 2016 from https://archive.org/details/ colouredfigureso00sowe

Webster, J. 1980: Introduction to Fungi. Cambridge University Press: Cambridge, UK. 
